\title{
Development of Problem Based Learning Tools to Improve Students' Problem Solving Ability and Metacognition Ability
}

\author{
Randi Tampubolon ${ }^{1, *}$ Bornok Sinaga $^{2}$ Mulyono $^{3}$
}

\author{
${ }^{1,2,3}$ Department of Postgraduate Mathematics Education, State University of Medan, Jl. William Iskandar Ps. V, \\ Kenangan Baru, Kabupaten Deli Serdang, Sumatera Utara 20371 \\ *Corresponding author.Email:matematikarandi@gmail.com
}

\begin{abstract}
This study aims to determine: 1) the level of validity, practicality and effectiveness of problem-based learning tools in improving students' problem-solving and metacognitive abilities, 2) increasing students' mathematical problemsolving abilities and students' metacognitive abilities in applying the developed problem-based learning tools. . This development research uses the Dick and Carey development model. The learning tools produced from this study are the lesson plan (RPP), student worksheets (LKPD), teacher handbooks (BPG), student books (BS), as well as problem solving ability tests (TKPM) and students' metacognition ability tests ( TKMS). . The subjects in this study were students of class X at SMA Negeri 17 Medan. The instruments used in this study were the validation sheet, the implementation observation sheet, and the test. The results of this study indicate that: 1) The learning tools developed meet the valid, practical and effective criteria in terms of their respective criteria. 2) There was an increase in the $\mathrm{N}$ Gain of students' problem solving abilities using problem-based tools developed in the first trial of 0.32 in the low category, an increase in the second trial of 0.53 in the moderate category. And there was an increase in the N-Gain of students' metacognition abilities using problem-based devices developed in the first trial of 0.29 in the low category in the second trial of 0.47 in the moderate category.
\end{abstract}

Keywords: Development of Learning Devices, Problem Based Learning, Problem Solving Ability, Student Metacognition Ability, and Dick and Carey Model.

\section{INTRODUCTION}

In the whole process of education in schools, learning activities are the most basic activities. This means that the success or failure of achieving educational goals depends a lot on how the learning process experienced by students as learners. [1] "Learning is an activity carried out by a person to acquire skills, skills and attitudes". The activity in question is a person's experience resulting in a relatively permanent change in mental structure. Learning experiences are reactions or mental actions of a person to the information or objects being studied. Learning mathematics is a psychological process in the form of a person's actions / efforts to reconstruct, understand or master mathematical material.

Mathematics plays a very important role in life. This can be seen in the assistance of mathematics in various sectors of human life, such as in computing, transportation, communication, economics and the development of science and technology. Mathematics is a universal science that is useful for human life and also underlies the development of modern technology which has an important role in various disciplines and advances human thinking. [2] Mathematics is a means or way to find answers to problems faced by humans; a way of using information, using knowledge of shapes and sizes, using knowledge of calculating, and most importantly thinking in humans themselves to see and use relationships in solving problems.

Problem solving ability is the ability of students to solve mathematical problems by observing the process of finding answers based on problem solving steps, namely understanding the problem, planning problem solving, solving problems, and double checking [3]. Although mathematics is a very important subject in the world of education and has a lot to do with everyday life, mathematics is still considered a frightening specter for students. [4] Students tend to be afraid and find it difficult to learn mathematics, generally in mathematical problems that are made as complex, so that students find it difficult to solve mathematical problems, which results in low students' mathematical problem solving abilities, while the low ability of students to solve mathematical 
problems is caused by students experiencing difficulty in understanding mathematical problems that affect the problem-solving process.

Schoenfeld [5] states that problem solving is a process in terms of understanding a problem to planning its solution and implementing it. Students' awareness in solving problems is very important because through this awareness students can find out whether the solution process is correct and to what extent the truth is, and students can evaluate the location of the solution errors in concept or procedural errors. This awareness is known as metacognition

Metacognition includes higher order thinking which involves active control during the cognitive learning process. In simple terms, metacognition is defined as "thinking in thinking". Metacognition consists of two components, namely knowledge and regulation. Metacognitive knowledge consists of self-knowledge as students and the factors that can influence it, knowledge about strategies, knowledge about when and why to use strategies. Metacognitive setting is a person's monitoring of cognition and includes planning activities, awareness of understanding and performance tasks, evaluation of process effectiveness, and strategy [6].

According to NCREL [7] students are said to have metacognitive abilities in problem solving if students are able to: (1) develop action plans, (2) organize or monitor completion actions, and (3) evaluate completion actions. At the stage of developing an action plan, it is hoped that students will be able to explain the prerequisite material for solving problems, write down plans for solving problems, and determine the completion time plan and the reasons. At the stage of monitoring the completion action it is hoped that students can explain the reasons for rethinking in understanding the problem so that it can be solved by themselves, explain how to solve the problem completely, and explain high confidence in the problem-solving process they are doing. Furthermore, at the stage of evaluating the completion action, it is expected that students can explain the reasons for solving the problem based on their own understanding, explain how to re-examine the answers that have been made, and describe what they learned after solving the problem.

Based on the results of the 2015 TIMSS (Trend in International Mathematics and Science Study), Indonesian students are ranked 44th out of 49 countries, with a score of 397 out of a score of 500 (Syamsul \& Novaliyosi, 2019: 563). The results of the Program for International Student Assessment (PISA) in 2018 show that Indonesian students are ranked 72 out of 77 countries in the world. Based on the low ability of students' mathematical problem solving, it is necessary to develop a learning tool that can help students improve their problem solving abilities. [8]
In line with the results of preliminary observations at SMA Negeri 17 Medan, the facts show that the problem solving abilities of students are still low. The low problem solving ability can be seen from the results of the diagnostic test in the form of story questions that the researcher gave to 36 class $X$ students on the Trigonometry material, namely: of the 36 students who took the diagnostic test, only 12 students (33.33\%) passed. The problem that occurs is that the problemsolving ability is low, namely the teacher has difficulty in arranging mathematics learning tools. Based on the results of interviews with teachers in the field of mathematics studies at SMA Negeri 17 Medan, so far students' problem solving abilities and metacognitive abilities have not been the focus of learning activities. On the other hand, researchers found that none of the teachers had learning tools that focused on practicing students' problem solving abilities and metacognition abilities.

In an effort to improve the process of teaching and learning mathematics in the classroom, efforts are needed to improve teacher and student understanding and the materials used for learning and interactions between students and teachers. In the implementation of learning, learning tools play an important role in the learning process, which is stated in Permendikbud Number 65 of 2013 concerning Basic and Secondary Education Process Standards, which states that the preparation of learning tools is part of learning planning. The learning tools are in the form of Learning Implementation Plans (RPP), Student Books (BS), Student Worksheets (LKPD), evaluation instruments or learning outcomes tests and learning media. As reinforced by the statement of Sanjaya [9] which states that "the teacher is able to correctly predict the success that will be achieved, through a careful and accurate planning process, besides that the learning process will develop in a directed and organized manner, and the teacher can use the time as effectively as possible to obtain the success of the learning process".

In order for the learning objectives to achieve the expected goals, it is necessary to select an appropriate learning model, and it is necessary to develop learning tools that are also in accordance with the learning model used. The learning model used must be able to make students active in learning activities, make learning meaningful, and be able to train students to get used to solving problems in solving problems. The purpose of holding learning device development is to produce a new product that is valid, effective and practical by using a learning-based model. problem (problem based learning). PBL is a learning model that prioritizes the use of actual problems as a context for students to learn critical thinking and problem solving skills and obtain essential concepts and knowledge from other lessons. [10] 
The choice of problem-based learning in this study is also because problem-based learning can improve students' higher order thinking skills. As the results of research [11] which found that problem-based learning can improve students' problem-solving abilities and selfefficacy. In line with the results of the study [8] found that the development of Problem Based Learning (PBL) based learning tools can improve students' problemsolving abilities. Likewise, the results of research [5] found that the development of problem-based learning model-oriented learning tools can improve students' metacognition abilities.

Based on the problems that have been described, the objectives of this study are: 1) validating, practicing, and making effective problem-based learning tools developed to improve students 'problem solving abilities and metacognition abilities, 2) improving students' problem solving abilities and metacognition abilities by using the tools developed problem-based learning.

\section{THEORICAL REVIEW}

\section{A. Problem Solving Ability}

In general, the definition of ability according to KBBI (Big Indonesian Dictionary) is an ability, a person's ability to do something. A person is said to have the ability or ability if he can and is able to do something that really should be done. Ability is power (strength) to do an action. Abilities can also be innate abilities, or they can be the result of practice or practice. From this understanding it can be concluded that ability is the ability to do something. Furthermore, mathematical ability is the ability to solve problems related to mathematical problems.

According to NCTM (National Council of Teachers of Mathematics) [12] in Nasution states that "mathematics power consists of 5 types of abilities, namely: (1) problem solving, (2) reasoning and proof. and proof), (3) connection, (4) communication, and (5) representation". Problem solving ability is the ability of students to solve mathematical problems by observing the process of finding answers based on problem solving steps, namely understanding the problem, planning problem solving, solving problems, and double checking [3].

Indicators that show problem-solving abilities According to Polya in Nuralam [13], among others:

a. Identify the elements that are known, in question, and the adequacy of the elements needed,

b. Formulating mathematical problems or compiling mathematical models,

c. Implementing strategies to solve various problems (types and new problems) in or outside mathematics, d. Explain or interpret the results according to the original problem, and

e. Use math meaningfully.

\section{B. Metacognition Ability}

Metacognition (metacognition) consists of the prefix "meta" and the word "cognition". Meta is a prefix for cognition which means "after" cognition. The definition of metacognition was first introduced by Flavell [14] from Stanford University by saying "Metacognition refers to one's knowledge concerning one's own cognitive processes and products or anything related to them, e.g., the learning-relevant properties of information or data. Metacognition refers, among other things, to the active monitoring and consequent regulation and orchestration of these processes in relation to the cognitive objects or data on which they bear, usually in the service of some concrete goal or objective ". The definition of Flavell's statement shows that metacognition is a person's knowledge of metacognition which is someone's knowledge of cognitive processes, products or anything related to their thought processes, among others, learning about the relationship between the properties of information or data. Metacognition ability is related to the thinking process of students about thinking in order to find the right strategy in solving problems.

Problem posing is one simple strategy in developing students' metacognition. This can be done classically or individually or in groups in the form of problem posing. Particularly in solving mathematical problems, one that is often referred to is the staging by Polya [15], who suggests four important stages that need to be done, namely:

1) Understanding the problem, including understanding the various things that exist in the problem such as what is unknown, what data is available, what are the conditions, and so on.

2) Thinking of a plan, including various attempts to find the relationship between the problem and other problems or the relationship between data and unknown things, and so on. Ultimately one must choose a solution plan.

3) Carry out the plan, including checking each step of the solution, whether the steps taken are correct or can be proven that the steps are correct.

4) Looking back, includes testing the resulting solution

In this case, metacognition involves the knowledge and awareness of a person about his own cognitive activity or everything related to his cognitive activity. In other words, metacognition is a person's awareness of what he knows and what to do with this knowledge and when he should use that knowledge. So that when he faced a problem, he knew what to do. 


\section{Problem Based Learning}

Problem-based learning, which is often known as Problem Based Instruction (PBI) or Problem Based Learning (PBL), is a learning model that uses problems as learning starting points. Problems that can be used as learning tools are problems that meet the real world context, which is familiar with students' daily lives. According to Arends in Nisak [16] states that the problem-based learning model is an approach in learning so that students can find solutions to real problems that affect their own knowledge, increase independence, selfconfidence, inquiry abilities and high-stage thinking skills. Therefore, there is a need for a learning model or an effective approach to thinking processes at a more difficult level related to mathematical problems so that they can be linked to the surrounding environment such as a problem based learning model.

According to Trianto [17], the characteristics (characteristics) of problem-based learning are:

1) Submission of questions or problems. Problem-based learning that organizes teaching with questions or problems must meet the following criteria:

a) Authentic: that is, the problem must be more rooted in the real world.

b) Clear: namely the problem is clearly formulated, in the sense that it does not cause new problems which in the end make it difficult to resolve.

c) Easy to understand: that is, the problem given should be easy to understand. In addition, problems are arranged and made according to the level of development of students.

d) Broad and in accordance with the learning objectives: namely the problems that are compiled and formulated should be broad, meaning that the problem includes all subject matter to be taught in accordance with the available time, space and resources. In addition, the problems that have been compiled must be based on predetermined learning objectives.

e) Useful: namely the problems that are compiled and formulated must be useful, both for students as problem solvers and educators / lecturers as problem makers. Useful problems are problems that can increase students' motivation to learn.

2) Focusing on interdisciplinary linkages. The problem to be investigated has been chosen to be really real so that in solving the student, the problem will be reviewed from many subjects.

3) Authentic investigation. Students are required to analyze and define problems, develop hypotheses, make predictions, collect and analyze information, conduct experiments (if needed), make inferences, and formulate conclusions.

4) Produce products and serve them. The product can be a report, a physical model, a video or a computer program.
5) Collaboration. Problem-based learning is characterized by students working together with one another, in pairs or in small groups.

From there it can be concluded that the characteristics of the problem-based learning model are learning that is characterized by presenting clear realworld problems using small groups to get a solution then students demonstrate what they have got.

\section{RESEARCH METHODS}

This type of research is development research. The development model used is the Dick and Carey development model which consists of 10 development stages.

The subjects in this study were students of class $\mathrm{X}$ IPA-1 and X IPA-2 SMA Negeri 17 Medan in the academic year 2020/2021, each class consisting of 36 students. While the object in this study is a class $\mathrm{X}$ high school mathematics learning device oriented problembased learning model developed by trigonometric material. The learning tools developed are in the form of a Learning Implementation Plan (RPP), Teacher's Manual (BPG), Student Book (BS), and Student Worksheets (LKPD). The development of the device was carried out using the Dick and Carey (2015) development model which consisted of ten development stages, namely: (1) identifying instructional objectives; (2) conduct an instructional analysis, (3) identify the initial behavior / characteristics of students; (4) formulating performance objectives; (5) developing an assessment instrument; (6) developing teaching strategies; (7) developing and selecting learning materials; (8) designing and implementing formative evaluations; (9) instructional revisions, and (10) developing and implementing summative evaluations. The entire development stage of the Dick and Carey model is modified in this study as shown in Figure 1 below:

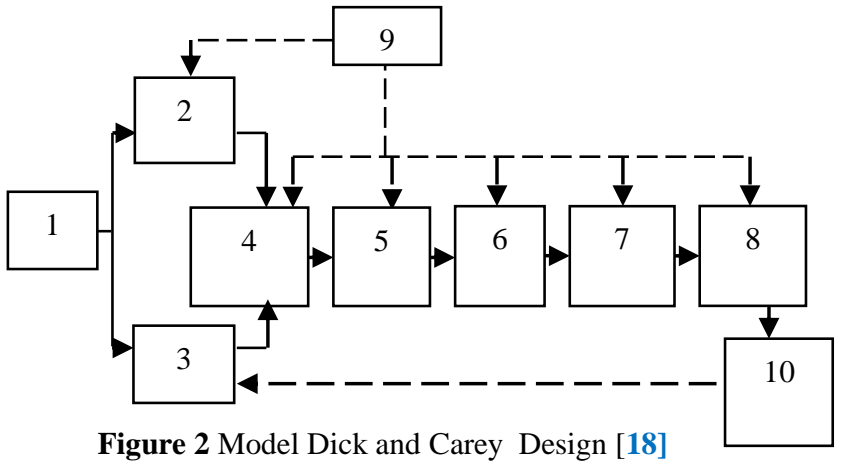

Information :

$=$ Activity process

$=$ Main groove

$=$ Occurs cvcles if needed

The instruments used in this study included instruments for assessing the quality of learning tools 
which included 3 aspects, namely aspects of validity, practicality and effectiveness. The instruments used were observation sheets, questionnaires, and tests. For details, it can be seen in Table 1 below

Table 1. Research Instruments

\begin{tabular}{|c|c|c|c|}
\hline Aspect & Instruments & Data Obtained & Respondents \\
\hline Valid & $\begin{array}{l}\text { Validation } \\
\text { sheet }\end{array}$ & $\begin{array}{l}\text { The validity of RPP, } \\
\text { LKPD, BS, BPG, and } \\
\text { Problem Solving } \\
\text { Ability Test }\end{array}$ & $\begin{array}{l}\text { Experts and } \\
\text { Practitioners }\end{array}$ \\
\hline \multirow{3}{*}{ Practical } & $\begin{array}{l}\text { Validation } \\
\text { sheet }\end{array}$ & $\begin{array}{l}\text { Validator's } \\
\text { assessment of the } \\
\text { ease of use of the } \\
\text { device }\end{array}$ & $\begin{array}{l}\text { Experts and } \\
\text { Practitioners }\end{array}$ \\
\hline & $\begin{array}{l}\text { Interview } \\
\text { guidelines }\end{array}$ & $\begin{array}{l}\text { The results of } \\
\text { interviews with } \\
\text { students and teachers } \\
\text { related to the ease of } \\
\text { use of learning tools. }\end{array}$ & $\begin{array}{c}\text { Teacher and } \\
\text { Student }\end{array}$ \\
\hline & $\begin{array}{l}\text { Observation } \\
\text { sheet }\end{array}$ & $\begin{array}{l}\text { Implementation of } \\
\text { learning tools }\end{array}$ & Observer \\
\hline \multirow{3}{*}{ Effective } & Test & \begin{tabular}{l}
\multicolumn{2}{l}{ Completeness of } \\
student learning \\
outcomes
\end{tabular} & $\begin{array}{c}\text { Research } \\
\text { Subject }\end{array}$ \\
\hline & $\begin{array}{l}\text { Observation } \\
\text { sheets }\end{array}$ & Student activities & Observer \\
\hline & Questionnaire & Student response & $\begin{array}{c}\text { Research } \\
\text { Subject }\end{array}$ \\
\hline $\begin{array}{c}\text { Increased } \\
\text { Ability }\end{array}$ & Test & N-Gain & $\begin{array}{c}\text { Research } \\
\text { Subject }\end{array}$ \\
\hline
\end{tabular}

The learning device is said to be valid if it meets the criteria for content validity and construct validity. For content validity, 5 validators provide a value of 1 to 5 in each assessment column which includes the following aspects: 1) format, 2) language, 3) content, and 4) illustrations. Problem-based learning tools meet the expected content validity if the average validator's assessment of all devices is then carried out construct validity on tests of students' problem-solving abilities and metacognition abilities. Before being used for field trials, the test items for problem-solving and metacognitive abilities were tested outside the research subject to measure the validity of the reliability, the distinguishing power and the level of difficulty. The validity of the items using learning was at the minimum valid criteria, namely the average value $\geqslant 4$ If not fulfilled, it is necessary to carry out the validation again. And so on until a learning device is obtained that meets the valid criteria. Furthermore, the construct validity was carried out on the test of students' problem-solving abilities and metacognition abilities. Before being used for field trials, the test items of students' problem solving abilities and metacognitive abilities were tested outside the research subjects to measure validity and reliability. The validity of the items used the Correlations Product Moment formula and the reliability used the AlphaCronbach formula [19]

The practicality of learning tools is reviewed based on the validators' assessment, teacher and student responses based on the results of interviews, and the implementation of learning tools. The validator's assessment is fulfilled if on the validation sheet all validators state that the learning device can be used easily. The results of the interview showed that the teacher and students stated that the devices could be used easily. The criteria for the implementation of learning devices are met if the percentage of learning device implementation is $\geqslant 80 \%$.

The effectiveness of learning devices is reviewed based on: 1) completeness of classical student learning outcomes based on tests of problem-solving abilities and tests of metacognitive abilities, 2) student activities during learning activities, and 3) student responses to learning components and devices. The completeness of student learning outcomes is seen based on the test results of problem-solving abilities and metacognition abilities. Classical completeness of student learning outcomes is fulfilled if $\geqslant 85 \%$ obtains a test score of $\geqslant$ 2.67 from a scale of 4 . Student activities are reviewed based on the average observer assessment of all meetings in each aspect of the activity observed. The effectiveness criterion based on student activity is achieved if it meets the percentage of ideal time tolerance set [1]. Student responses are reviewed based on students' answers to the questionnaire given. The effectiveness criteria based on student responses are fulfilled if classically $\geqslant 80 \%$ of the subjects respond positively, namely to all aspects being asked regarding the device and implementation of learning. The results of student responses were obtained when conducting field trials at the same time by seeing the ideal time and tolerance limits for student activity and student responses in learning

\section{RESULTS AND DISCUSSION}

\subsection{Research Result}

The development of learning tools has been completed using the Dick and Carey development model with the following details:

\subsubsection{Identify Instructional Goal}

Teaching objectives can be identified by first analyzing instructional needs. The process of identifying instructional needs starts from identifying problems in the field. Based on the diagnostic tests given, the students' problem solving abilities and metacognition abilities are still low. The results of observations and interviews with teachers and students indicate that the reason is that students are not used to solving problems and metacognition in learning activities. This is also supported by the condition of teachers who have not been able to compile learning tools that focus on developing students' problem-solving abilities and metacognitive abilities. Based on these findings, the main objective in developing this tool is to develop and 
improve students' problem solving abilities and metacognition abilities.

\subsubsection{Conduct Instructional Analysis}

Instructional analysis in this study is a process of describing general competencies into sub-competencies, basic competencies or special sub-competencies that are structured logically and systematically. This activity is intended to identify a list of sub-competencies and establish a relationship between one another towards

general competencies which in the 2013 curriculum are is

called core competencies. The material to be taught

trigonometric comparisons. So that the basic competencies of the material are described, and indicators are developed to achieve its success.

\section{Identify Entry Behaviors}

The cognitive development of research subjects at SMA Negeri 17 Medan entered the formal operational stage because they were in the age range 15-16 years. This stage uses a more logical, abstract, and idealistic way of thinking. The target subjects in class $\mathrm{X}$ are students who are quite diverse, both in terms of gender and students' cognitive abilities.

\section{Write Performance Objectives}

Writing the formulation of learning objectives is based on indicators to achieve the basic competencies that have been compiled in the second development stage. The learning objectives in this study are: (1) students can determine the basic concept of angles; (2) students can determine the ratio of angles; (3) students can determine the angle in the form of radians; (4) students can determine the value of sine, cosine, tangent, secant, cosecant, and cotangent in a right triangle; (5) students can solve trigonometric comparison problems related to problems in everyday life

\section{Develop Criterion Reference Tests}

At this stage, a learning outcome test is arranged to measure students' problem-solving abilities. The test is arranged based on the learning objectives to be achieved. Based on these objectives, an essay test of 4 problems was compiled and each problem was accompanied by questions on the problem-solving process and metacognition

\section{Develop Instructional Strategy}

Developing learning strategies, specifically to help learners achieve specific goals. In accordance with the essence of this study is to develop problem-based learning-oriented learning tools. The problem-based learning syntax can be seen in Table 2 below
Table 2. Syntax of Problem Based Learning

\begin{tabular}{|c|c|c|}
\hline No & Step & Teacher's Behavior \\
\hline 1. & $\begin{array}{ll}\text { Orientation } & \text { of } \\
\text { students } & \text { to } \\
\text { problems } & \end{array}$ & $\begin{array}{l}\text { The teacher explains the learning } \\
\text { objectives, explains the media needed, } \\
\text { motivates students to engage in problem- } \\
\text { solving activities they choose. }\end{array}$ \\
\hline 2. & $\begin{array}{l}\text { Organizing } \\
\text { students } \\
\text { learn }\end{array}$ & $\begin{array}{l}\text { The teacher helps students define and } \\
\text { organize learning tasks related to the } \\
\text { problem. }\end{array}$ \\
\hline 3. & $\begin{array}{l}\text { Guiding } \\
\text { individual and } \\
\text { group } \\
\text { investigations }\end{array}$ & $\begin{array}{l}\text { The teacher encourages students to } \\
\text { collect appropriate information, carry out } \\
\text { experiments to get explanations and } \\
\text { problem solving. }\end{array}$ \\
\hline 4. & $\begin{array}{l}\text { Develop and } \\
\text { present the } \\
\text { work }\end{array}$ & $\begin{array}{l}\text { The teacher assists students in planning } \\
\text { and presenting their work and assists } \\
\text { students in various assignments with their } \\
\text { friends. }\end{array}$ \\
\hline 5. & $\begin{array}{l}\text { Analyze and } \\
\text { evaluate the } \\
\text { problem- } \\
\text { solving } \\
\text { process }\end{array}$ & $\begin{array}{l}\text { The teacher helps students to reflect or } \\
\text { evaluate the selection of students and the } \\
\text { processes students use. }\end{array}$ \\
\hline
\end{tabular}

\section{Develop and Select Instructional Materials}

The main activity in this phase is the writing of the initial design of learning materials which includes Student Worksheets (LKPD), Teacher Manuals (BPG), Student Books (BS) and Problem Solving Ability Tests (TKPM). The learning materials that are prepared are based on $\mathrm{KI}, \mathrm{KD}$, and indicators on the trigonometric comparison material, and are adjusted with the aim of training and improving students' problem solving abilities. All learning tools are one unit in a problembased learning model.

\section{Develop and Construction Formative Evaluation}

At this stage, an evaluation of the learning tools that have been developed is carried out. Formative evaluation is carried out in 2 stages, namely: 1) one-onone evaluation by experts and practitioners, and 2) field trials. The goal is to see weaknesses and improve the tools that have been developed. The results of one-onone evaluations by experts and practitioners in the form of content validity assessment indicate that all learning devices meet the valid criteria can be seen in Table 3

Table 3. Summary of Learning Device Validation Results

\begin{tabular}{|c|c|c|c|}
\hline No & $\begin{array}{c}\text { The object } \\
\text { being assessed }\end{array}$ & $\begin{array}{c}\text { The average value } \\
\text { of the total validity }\end{array}$ & $\begin{array}{c}\text { Validation } \\
\text { Level }\end{array}$ \\
\hline 1 & RPP & 4,47 & \\
2 & LKPD & 4,34 & Valid \\
3 & BPG & 4,38 & \\
4 & BS & 4,34 & \\
\hline
\end{tabular}

After the learning device is said to be valid, then the validity and reliability test is carried out and we can see it in Table 4. 
Table 4. Results of the Validity and Reliability of Question Items

\begin{tabular}{|c|c|c|c|c|c|}
\hline \multicolumn{6}{|c|}{ Problem Solving Ability Test } \\
\hline No & $r_{x y}$ & $t_{\text {hitung }}$ & $t_{\text {tnibel }}$ & $F_{11}$ & Interpretation \\
\hline 1 & 0,895 & 11,699 & 2,05 & \multirow{4}{*}{0,922} & \multirow{4}{*}{$\begin{array}{l}\text { Valid and } \\
\text { Very High }\end{array}$} \\
\hline 2 & 0,909 & 12,716 & 2,05 & & \\
\hline 3 & 0,911 & 12,880 & 2,05 & & \\
\hline 4 & 0,897 & 11,832 & 2,05 & & \\
\hline \multicolumn{6}{|c|}{ Student Metacognition Ability Test } \\
\hline No & $r_{x y}$ & $t_{\text {hitung }}$ & $t_{\text {trubel }}$ & $r_{11}$ & Interpretation \\
\hline 1 & 0,909 & 12,716 & 2,05 & \multirow{4}{*}{0,934} & \multirow{4}{*}{$\begin{array}{l}\text { Valid and } \\
\text { Very High }\end{array}$} \\
\hline 2 & 0,933 & 15,117 & 2,05 & & \\
\hline 3 & 0,941 & 16,214 & 2,05 & & \\
\hline 4 & 0,894 & 13,013 & 2,05 & & \\
\hline
\end{tabular}

From the results of the validity and reliability of the items, it can also be distinguished by the good category and the difficulty level of the items in the medium category.

Field trials or first trials were carried out to see the practicality and effectiveness of learning devices. In the first trial, the learning devices did not meet all the practical and effective criteria, so a revision had to be made to the learning device and the second trial was conducted

\section{Description of Trial Results I}

Trial I was carried out in class X IPA-2 and what will be done is to measure the level of practicality, level of effectiveness and increase in students' abilities to learning tools developed with a problem-based model. The criteria for the practicality of learning devices based on the validator's assessment are met, because all validators assess the learning tools developed can be used easily. The results of the teacher and student interviews obtained information that learning tools can be used easily. The implementation of learning tools is fulfilled, in terms of the average of all learning meetings getting a percentage of $81.46 \%$ (good category). Based on this description, the learning tools developed meet practical criteria.

The results of the test of problem-solving and metacognition abilities classically show that the number of subjects who completed a score of $\geqslant 2.67$ reached 14 out of 36 students or $38.89 \%$. So that it does not meet the criteria for the expected completeness of classical learning outcomes.

Student response data were filtered to see the extent of interest, feelings of pleasure, recency, and ease of students in understanding the components of the developed problem-based learning model-oriented learning tools. Positive responses are characterized by positive statements such as happy, new, interested, clear, interested, while negative statements are characterized by statements such as displeasure, not new, not interested, unclear and not interested in using the component of problem-based learning tools. The results of the student response questionnaire data analysis to the learning device components developed are presented in Table 5 below:

Table 5. Student Responses in Trial I

\begin{tabular}{|c|c|c|c|}
\hline \multirow{2}{*}{ No } & \multirow{2}{*}{ Aspect } & \multicolumn{2}{|c|}{ (\%) Average } \\
\hline & & Happy & Not Happy \\
\hline 1 & $\begin{array}{l}\text { Students feel happy } \\
\text { about the learning } \\
\text { component. }\end{array}$ & 94,44 & 5,46 \\
\hline \multicolumn{2}{|r|}{ Answer } & New & Not New \\
\hline 2 & $\begin{array}{l}\text { Student response to } \\
\text { the novelty of the } \\
\text { learning component. }\end{array}$ & 91,67 & 8,33 \\
\hline \multicolumn{2}{|r|}{ Answer } & Interested & Not Interested \\
\hline 3 & $\begin{array}{l}\text { Student response to } \\
\text { interest in following } \\
\text { further learning. }\end{array}$ & 97,22 & 2,78 \\
\hline \multicolumn{2}{|r|}{ Answer } & Clear & Not Clear \\
\hline 4 & $\begin{array}{l}\text { Student assessment } \\
\text { of the clarity of the } \\
\text { language used. }\end{array}$ & 91,67 & 8,33 \\
\hline \multicolumn{2}{|r|}{ Answer } & Interested & Not Interested \\
\hline 5 & $\begin{array}{l}\text { Student response to } \\
\text { interest in } \\
\text { appearance (writing, } \\
\text { illustrations } \\
\text { pictures and image } \\
\text { layouts). }\end{array}$ & 91,67 & 8,33 \\
\hline \multicolumn{2}{|r|}{ Overall Average } & 93,33 & 6,73 \\
\hline
\end{tabular}

Of all the students gave a positive response to the learning tools provided so that it reached $89.11 \%$ stating that the students' responses were very positive.

Then in knowing the level of students 'problem solving abilities and students' metacognition abilities obtained from the pre-test and post-test data. Improved problem solving abilities are presented in Table 6 below

Table 6. Improved Problem Solving Ability and Metacognition Ability Trial I

\begin{tabular}{|l|c|c|c|}
\hline $\begin{array}{c}\text { Ability } \\
\text { Enhancement }\end{array}$ & $\begin{array}{c}\text { Average N- } \\
\text { Gain Value }\end{array}$ & $\begin{array}{c}\text { N-Gain } \\
\text { Percent } \\
\text { Value }\end{array}$ & Criteria \\
\hline $\begin{array}{l}\text { Problem } \\
\text { Solving }\end{array}$ & 0,32 & $32,41 \%$ & Low \\
\hline Metacognition & 0,29 & $28,81 \%$ & Low \\
\hline
\end{tabular}

Overall the learning tools developed meet the valid and practical criteria, but do not yet meet the effectiveness criteria. This is because the aspects of completeness of classical student learning outcomes have not been fulfilled. Thus the learning device must be revised and then tested II. For Trial II, it was carried out in a different class, namely in class X IPA-1. 


\section{Revisions Instructional}

Revisions are made based on the findings of device weaknesses in the I trial. Revisions are made to the lesson plans related to the allocation of learning time, as well as to the LKPD and BS related to the material being taught. After the revision is complete, a follow-up field trial or trial II is carried out to review the practicality and effectiveness of the learning device, as well as the improvement of students' problem-solving abilities and metacognition abilities between trials.

\section{Description of Trial Results II}

The criteria for practicality of learning devices based on the validator's assessment were fulfilled in accordance with the description in trial I. The implementation of learning tools in the second trial was also fulfilled, in terms of the average of all learning meetings obtained a percentage of $89.13 \%$ (good category). Based on this description, the learning tools developed meet practical criteria.

The results of the classical problem-solving ability test showed that the number of subjects who completed a score of $\geqslant 2.67$ reached 33 students out of 36 students or $91.67 \%$ and the results of the metacognition ability classically showed the number of subjects with a score of $\geqslant 2.67$ reaching 31 students out of 36 students or $89.11 \%$ who complete get a score so that the criteria for completeness of classical learning outcomes are in accordance with what is expected. The average percentage of ideal time for student activities in the criteria met in each activity.

Student response data were filtered to see the extent to which students' interest, feeling of pleasure, recency, and ease in understanding the components of the learning device oriented to the developed problem-based learning model, for student responses to Trial II are presented in the Table 7 following
Table 7. Student Responses in Trial II

\begin{tabular}{|c|c|c|c|}
\hline \multirow[b]{2}{*}{ No } & \multirow[b]{2}{*}{ Aspect } & \multicolumn{2}{|c|}{ (\%) Average } \\
\hline & & Нарру & $\begin{array}{c}\text { Not } \\
\text { Happy }\end{array}$ \\
\hline 1 & $\begin{array}{l}\text { Students feel happy about } \\
\text { the learning component . }\end{array}$ & 91,67 & 8,33 \\
\hline \multicolumn{2}{|r|}{ Answer } & New & Not New \\
\hline 2 & $\begin{array}{l}\text { Student response to the } \\
\text { novelty of the learning } \\
\text { component. }\end{array}$ & 87,78 & 12,22 \\
\hline \multicolumn{2}{|r|}{ Answer } & Interested & $\begin{array}{c}\text { Not } \\
\text { Interested }\end{array}$ \\
\hline 3 & $\begin{array}{l}\text { Student response to } \\
\text { interest in following } \\
\text { further learning. }\end{array}$ & 97,22 & 2,78 \\
\hline \multicolumn{2}{|r|}{ Answer } & Clear & Not Clear \\
\hline 4 & $\begin{array}{l}\text { Student assessment of the } \\
\text { clarity of the language } \\
\text { used. }\end{array}$ & 90,28 & 9,72 \\
\hline \multicolumn{2}{|r|}{ Answer } & Interested & $\begin{array}{c}\text { Not } \\
\text { Interested }\end{array}$ \\
\hline 5 & $\begin{array}{l}\text { Student response to } \\
\text { interest in appearance } \\
\text { (writing, illustrations / } \\
\text { pictures and image } \\
\text { layouts). }\end{array}$ & 86,11 & 13,89 \\
\hline \multicolumn{2}{|r|}{ Overall Average } & 89,81 & 10,19 \\
\hline
\end{tabular}

Of all the students gave a positive response to the learning tools provided so that it reached $93.33 \%$ stating that the students' responses were very positive.

Then in knowing the level of students' problem solving abilities obtained from the pre-test and post-test data. The improvement of students' problem solving abilities and metacognition abilities is presented in the Table 8

Table 8. Improved Problem Solving Ability and

\begin{tabular}{|l|c|c|c|}
\hline $\begin{array}{c}\text { Ability } \\
\text { Enhancement }\end{array}$ & $\begin{array}{c}\text { Average N- } \\
\text { Gain Value }\end{array}$ & $\begin{array}{c}\text { N-Gain } \\
\text { Percent } \\
\text { Value }\end{array}$ & Criteria \\
\hline Problem Solving & 0,53 & $53,24 \%$ & Moderate \\
\hline Metakognisi & 0,47 & $46,66 \%$ & Moderate \\
\hline
\end{tabular}

Metacognition Ability Trial II

From Table 8 above shows that the N-Gain results of students reviewed based on the average value of the pre-test and post-test problem solving abilities and metacognition abilities have increased. Thus the use of learning tools oriented to the developed problem based learning model can improve students' problem solving abilities in trial II

\section{Developing and Implementing a Summative Evaluation}

Summative evaluation in this study was not carried out. This is because summative evaluation is not part of the instructional design process [19]. Formative evaluation and summative evaluation cannot be combined as two consecutive activities, but interspersed 
with an implementation period [9] so that it takes a long time and costs a lot to do it.

\section{ConClusions}

Based on the results of the analysis and discussion in this study, several conclusions were made as follows: 1) The developed problem-based learning tools meet the valid criteria, in terms of: a) content validity and b) construct validity; The developed problem-based learning tools meet practical criteria, in terms of: a) the validator's assessment of learning devices, b) student and teacher interviews about the ease of use of the device, and c) the implementation of learning tools; The developed problem-based learning tools meet the criteria of being effective, in terms of: a) completeness of classical student learning outcomes b) student activities in learning activities, and c) positive student responses. 2) The problem-solving abilities and metacognition abilities of students using the developed problem-based learning tools increased, in terms of the students' N-Gain acquisition at the end of the trial to the moderate category.

\section{ACKNOWLEDGMENT}

On this occasion the author would like to express his sincere gratitude and highest appreciation to all those who have helped the author, to the family who have supported the author in everything. Mr. Prof. Dr. Pargaulan Siagian, M.Pd, Dr. Pardomuan Sitompul, M.Si, Mangaratua Smanjorang, P.hD as the my thesis resource, as well as the Head of the Pemprovsu Service, the Principal of SMA Negeri 17 Medan, as well as teachers and administrative staff who have given permission and opportunity for the author to conduct research at the school.

\section{REFERENCES}

[1] Sinaga, B. (2008). Development of Mathematics Learning Model Based on Problems Based on Batak Culture (PBMB3). Research Result Report: Competitive Grant. State University of Medan

[2] Hasratuddin, (2018). Why do you have to study mathematics. Second printing: Perc. EDIRA. ISBN: 978-602-6970-45-9

[3] Havill, J (2020). How to Solve It. In Discovering Computer Science

[4] Bayuningsih, A. S., Usodo, B., \& Subanti, S. (2017). Analysis of Junior High School Students' Problem-solving Ability Reviewed from Selfregulated Learning. International Journal of Science and Applied Science: Conference Series, 2(1), 51 .

[5] Amir, MF \& W Kusuma MD (2018). Development of Contextual Problem Based Learning Tools to
Improve Metacognition Ability of Elementary School Students. Ivet: Journal Of Medives, 2 (1),

[6] Ozturk, N. (2017). Assessing Metacognition: Theory and Practices. International Journal of Assessment Tools in Education (IJATE), 4(2), 134-148.

[7] North Central Regional Educational Laboratory (NCREL).(2007). Metacognition.

[8] Silalahi FCG., Kartini., \& Hutapea NM (2021). Development of Mathematics Learning Tools Based on Problem Based Learning Models to Facilitate Mathematical Problem Solving Ability for Class VIII Junior High School Students. Journal of Cendikia: Journal of Mathematics Education, 5 (1), 113-124.

[9] Mustafa PS., \& Winarno (2020). Textbook Development of Remedial Teaching in Physical Education for Undergraduate Students of Physical Education and Health, State University of Malang. Multilateral: Journal of Physical Education and Sports 19 (1), 1-20

[10] Suharini, E., \& Handoyo, E. (2020). Effectiveness of Problem Based Learning Model Assisted by Pocket Book toward Student Self-Efficacy. 29(10), 1199-1204

[11] Safithri, R., Syaiful., \& Huda N (2021). The Effect of the Application of Problem Based Learning (PBL) and Project Based Learning (PjBL) on Problem Solving Ability Based on Student Self Efficacy. Journal of Cendikia: Journal of Mathematics Education, 5 (1), 335-346

[12] Suharini, E., \& Handoyo, E. (2020). Effectiveness of Problem Based Learning Model Assisted by Pocket Book toward Student Self-Efficacy. 29(10), 1199-1204.

[13] Waluyo E., \& Nurani. (2021). Development of Tpack Integrated Inquiri Learning Instructional Design Design to Improve Problem Solving Ability. JPPM: Journal of Mathematics Learning Development. 3 (1). 1-11.

[14] Nurvita, Sinaga B, \& Mukthar. (2019). Analysis of Metacognition Difficulties and Students' Mathematical Connections Using the Jigsaw-Type Cooperative Learning Model at SMP N 1 Lawe Bulan, Aceh Tenggara. Paradikma: Journal of Mathematics Education. 12 (1). 1 - 6

[15] Santoso FE, Napitupulu E, \& Amry Z. (2018). Metacognition Analysis of Students in Mathematical Problem Solving Ability in Problem Based Learning (PBL) Learning Model. Paradikma: Journal of Mathematics Education. 11 (1) .1-14

[16] Suwanti, Prasetyo E, Dhema M, \& Rusdin M E. (2021). Improving the Ability of Problem Solving in 
Mathematics through Problem Based Learning (PBL) Learning Model. 6 (1). 7-12

[17] Rahmadani D, Siagian P, \& Napitupulu E (2019). Development of Problem Based Learning Tools to Improve Learning Independence of Binjai State Senior High School Students. Paradikma: Journal of Mathematics Education. 12 (2). 1-5.
[18] Dick W, Corey L,\& Corey J O. (2015). The Systematic Design of Intruction. Eighth Edition. Pearson

[19] Sugiyono. (2019). Statistics For Research. Bandung: Alfabeta 